\title{
Multi-walled Carbon Nanotubes Modified Screen-Printed Electrode Coated Bismuth Oxide Nanoparticle for Rapid Detection of $\mathrm{Cd}(\mathrm{II})$ and $\mathrm{Pb}(\mathrm{II})$
}

\author{
Hao $\mathrm{Cui}^{1, *}$ and Qingde $\mathrm{Li}^{2}$ \\ ${ }^{1}$ School of Fine Arts and Art Design, Qiqihar University, Qiqihar City, 161006, China; \\ ${ }^{2}$ School of Industrial Design and Ceramic Art, Foshan University, Foshan City, 528000, China; \\ "E-mail: cuihaolunwen@163.com
}

doi: $10.20964 / 2019.07 .15$

Received: 5 March 2019 / Accepted: 20 April 2019 / Published: 10 June 2019

\begin{abstract}
Paint has a variety of excellent properties containing anti-corrosion, waterproof, oil-proof, chemicalresistant, light-resistant, temperature-resistant. The wooden furniture covered with paint is commonly used to ensure their excellent quality. However, the soluble heavy metals in the paint exist on the surface of wooden furniture, endangering human health when they are enriched in human bodies. Therefore, an effective detection method is needed to analyze the contents of heavy metals in wooden furniture. Here, we designed and manufactured a disposable screen-printed electrode (SPE) for the $\mathrm{Cd}(\mathrm{II})$ and $\mathrm{Pb}$ (II) determination through square wave anodic stripping voltammetry, which used a special printed ink mixed multi-walled carbon nanotube and coated with bismuth oxide nanoparticle (BONP-MSPE). The characteristics of BONP-MSPE were studied using cyclic voltammetry, electrochemical impedance spectroscopy and square-wave stripping voltammetry, and then the detecting conditions were optimized. Under the optimal conditions, the values of peak currents of $\mathrm{Cd}(\mathrm{II})$ and $\mathrm{Pb}$ (II) increased linearly with the concentrations of $\mathrm{Cd}$ (II) and $\mathrm{Pb}$ (II). The linear ranges were from 0.5 to $40 \mu \mathrm{g} / \mathrm{L}$ for $\mathrm{Cd}(\mathrm{II})$ and 0.5 to $40 \mu \mathrm{g} / \mathrm{L}$ for $\mathrm{Pb}(\mathrm{II})$, with detection limits of $0.5 \mu \mathrm{g} / \mathrm{L}$ and $0.05 \mu \mathrm{g} / \mathrm{L}(\mathrm{S} / \mathrm{N}=3)$, respectively, Lastly, the BONP-MSPE was further employed to measure the contents of $\mathrm{Cd}(\mathrm{II})$ and $\mathrm{Pb}$ (II) in pint samples analysis.
\end{abstract}

Keywords: Wooden furniture, Green furniture, Lead, Cadmium, Heavy mental, Screen-Printed Electrode, Bismuth oxide

\section{$\underline{\text { FULL TEXT }}$}

(C) 2019 The Authors. Published by ESG (www.electrochemsci.org). This article is an open access article distributed under the terms and conditions of the Creative Commons Attribution license (http://creativecommons.org/licenses/by/4.0/). 